\title{
INFORMATION SYSTEMS AND TECHNOLOGIES
}

DOI https://doi.org/10.30525/978-9934-26-109-1-1

\section{АЛГОРИТМ ЗБІЛЬШЕННЯ ЗОБРАЖЕННЯ НА ОСНОВІ ОПТИМІЗАЦІЇ МОМЕНТНО-ІНВАРІАНТНОЇ МЕТРИКИ}

\author{
Бедратюк Г. I. \\ старший викладач кафедри інженерії програмного забезпечення \\ Хмельницький наиіональний університет \\ м. Хмельнииький, Украӥна
}

Одним із найпоширеніших методів обробки зображень, яке часто зустрічається в прикладних застосуваннях, є масштабування, тобто збільшення, або зменшення розмірів растрового зображення без зміни його пропорцій. Останнім часом великий інтерес викликають алгоритми відновлення зображення з високою роздільною здатністю із зображень низької роздільної здатності, які мають загальну назву алгоритми із супер-роздільною здатністю (Super-Resolution). Останні роботи в цій області [1-5], які базуються на використанні згорткових нейронних меред, досягли значного покращення якості зображення. Проте задача відновлення зображення $\epsilon$ в цілому некорекно поставленою оберненою задачею, яка допускає неоднозначність розв'язку. Внаслідок чого виникає проблема - за якими критеріями відібрати потрібне збільшене зображення із багатьох можливих зображень? Інша подібна задача яка виникає це задача порівняння якості отриманих зображень отриманих різними методами, а також задача порівняння якості збільшеного зображення із оригіналом. Існує біля сотні різноманітних метрик, для вимірювання якості зображення, найбільш популярні 3 них - середня квадратична помилка (MSE), пікове співвідношення сигналу до шуму (PSNR), універсальний індекс якості зображення (UQI), індекс структурної схожості (SSIM), індекс дескрипторної схожості (FSIM), градієнтна міра подібності (GSM), міра рівня шуму (NQM). Проте не всі вони адекватно реагують на спотворення зображення при масштабуванні. Ми пропонуємо новий метод інтерполяції зображення як варіант задачі оптимізації на основі геометричних моментів зображення. Геометричним моментом порядку $p+q$ функції $f(x, y)$ називається вираз 


$$
m_{p q}(f(x, y))=m_{p q}=\iint_{\Omega} x^{p} y^{q} f(x, y) d x d y, \Omega \subset \mathbb{R}^{2} .
$$

Для дискретного бінарного зображення його геометричний момент $m_{0,0} \in$ кількістю білих пікселів. Також, в термінах моментів виражається координати центру мас зображення:

$$
\bar{x}=\frac{m_{10}}{m_{0,0}}, \bar{y}=\frac{m_{01}}{m_{0,0}} .
$$

Нормалізованим моментом $\mu_{p q}$ порядку $p+q$ називається вираз

$$
\eta_{p, q}=\frac{m_{p q}}{m_{00}^{\frac{p+q}{2}+1}} .
$$

Автором в [6] запопоновано ввести такі дві метрики як міру оцінки якості масштабування зображень

$$
\begin{gathered}
\rho_{1}\left(f, f^{\prime}\right)=\frac{1}{M N} \sum_{x=0}^{M-1} \sum_{y=0}^{N-1}\left(\eta_{p, q}-\eta_{p, q}^{\prime}\right)^{2}, \\
\rho_{2}\left(f, f^{\prime}\right)=\frac{1}{M N} \sum_{x=0}^{M-1} \sum_{y=0}^{N-1}\left|\eta_{p, q}-\eta_{p, q}^{\prime}\right|,(x, y) \neq(0,0) .
\end{gathered}
$$

Всяка інтерполяція зображень зводиться до присвоєння деяких значень новим пікселям збільшеного зображення. Якість збільшення можна подати як деяку функцію від цих нових значень пікселів, виражену в термінах нормалізованих моментів. Головна ідея методу полягає у виборі таких нових значень пікселів збільшеного зображенння, які мінімізують відстань між збільшенним зображеннням та оригіналом. Пропонується використати такі метрики як функцію втрат у процесі навчання згоркових нейронних мереж 3 метою зменшення часу навчання і покращення якості збільшених зображень.

\section{Лiтература:}

1. Ledig, Christian, et al. "Photo-realistic single image superresolution using a generative adversarial network." Proceedings of the IEEE conference on computer vision and pattern recognition. 2017.

2. Dong, Chao, et al. "Image super-resolution using deep convolutional networks." IEEE transactions on pattern analysis and machine intelligence 38.2 (2015): 295-307.

3. J. Kim, J. Kwon Lee, and K. Mu Lee, "Accurate image superresolution using very deep convolutional networks," in Proceedings of the IEEE Conference on Computer Vision and Pattern Recognition, 2016. P. 1646-1654 
4. Z. Li, J. Yang, Z. Liu, X. Yang, G. Jeon, and W. Wu, "Feedback network for image super-resolution," in Proceedings of the IEEE Conference on Computer Vision and Pattern Recognition, 2019. P. 3867-3876.

5. Z. Liu, L. Wang, C. Li, W. Siu, and Y. Chan, "Image superresolution via attention based back projection networks," in Proceedings of the IEEE International Conference on Computer Vision Workshop, 2019.

6. Бедратюк Г.І. Аналіз якості методів повороту зображення за допомогою моментних інваріантів. Вимірювальна та обчислювальна техніка в технологічних процесах. 2020. № 2. С. 56-6.

DOI https://doi.org/10.30525/978-9934-26-109-1-2

\title{
РОЗВИТОК КІБЕРЗАХИСТУ - ОДНА ІЗ СКЛАДОВИХ БЕЗПЕКИ УКРАЇНИ
}

\author{
Лаврут О. О. \\ доктор технічних наук, доиент, \\ професор кафедри тактики \\ Наиіональна академія сухопутних військ \\ імені гетьмана Петра Сагайдачного \\ Лаврут Т. В. \\ кандидат географічних наук, дочент, \\ старший науковий співробітник науково-дослідного відділу \\ (систем управління військами) \\ Наукового иентру Сухопутних військ \\ Національна академія сухопутних військ \\ імені гетьмана Петра Сагайдачного \\ Колесник В. О. \\ стариий науковий співробітник \\ Національна академія сухопутних військ \\ імені гетьмана Петра Сагайдачного \\ м. Львів, Украӥна
}

Ми живемо в епоху глобалізації, коли інформаційні технології та телекомунікаційні системи охоплюють усі сфери життєдіяльності людини, держави. Зростають обсяги інформації, що циркулює, 